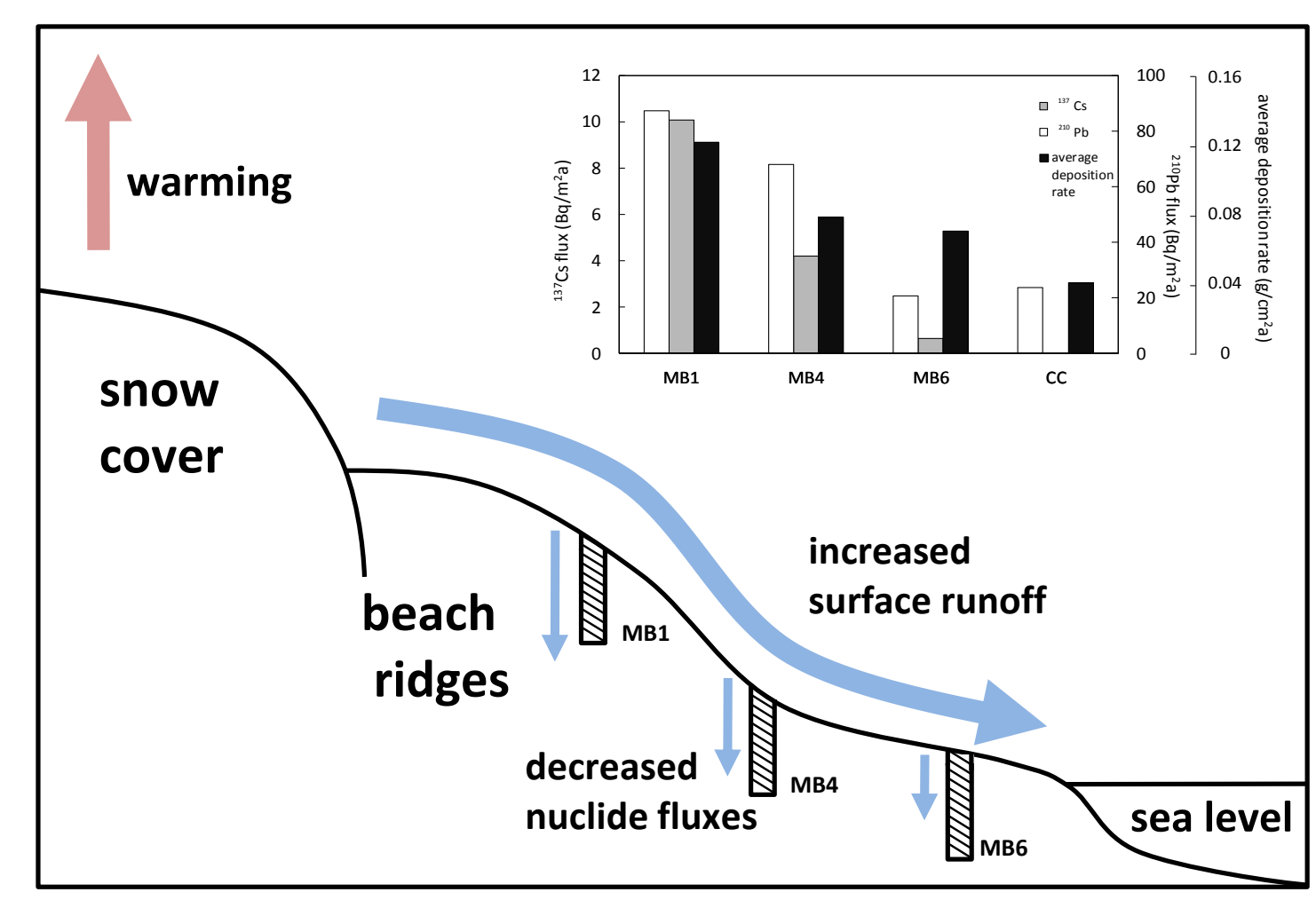




\title{
Radionuclides in ornithogenic sediments as evidence for recent warming in the Ross Sea region, Antarctica
}

\begin{abstract}
Yaguang $\mathrm{Nie}^{1,2}$, Liqiang $\mathrm{Xu}^{3}, \mathrm{Xiaodong}^{\mathrm{Li}}{ }^{1 *}$, Steven D. Emslie
${ }^{1}$ Institute of Polar Environment, School of Earth and Space Sciences, University of Science and Technology of P. R. China, Hefei 230026, China; ${ }^{2}$ Key Laboratory of Ion Beam Bioengineering, Hefei Institutes of Physical Science, Chinese Academy of Sciences, Key Laboratory of Environmental Toxicology and Pollution Control Technology Of Anhui Province, Hefei, Anhui 230031, P. R. China; ${ }^{3}$ School of Resources and Environmental Engineering, Hefei University of Technology, Hefei, Anhui 230009, China; ${ }^{4}$ Department of Biology and Marine Biology, University of North Carolina Wilmington, 601 S. College Road, Wilmington, NC 28403, USA.
\end{abstract}

*Correspondence should be addressed to Xiaodong Liu (ycx@ustc.edu.cn) 
Abstract: Radionuclides including ${ }^{210} \mathrm{~Pb},{ }^{226} \mathrm{Ra}$ and ${ }^{137} \mathrm{Cs}$ were analyzed in eight ornithogenic sediment profiles from McMurdo Sound, the Ross Sea region, East Antarctica. Equilibration between ${ }^{210} \mathrm{~Pb}$ and ${ }^{226} \mathrm{Ra}$ were reached in all eight profiles, enabling the determination of chronology within the past two centuries through the Constant Rate of Supply (CRS) model. Calculated fluxes of both ${ }^{210} \mathrm{~Pb}$ and ${ }^{137} \mathrm{Cs}$ varied drastically among four of the profiles (MB4, MB6, CC and CL2), probably due to differences in their sedimentary environments. In addition, we found the flux data exhibiting a clear decreasing gradient in accordance with their average deposition rate, which was in turn related to the specific location of the profiles. We believe this phenomenon may correspond to global warming of the last century, since warming-induced surface runoff would bring more inflow water and detritus to the coring sites, thus enhancing the difference among the profiles. To verify this hypothesis, the deposition rate against age of the sediments was calculated based on their determined chronology, which showed ascending trends in all four profiles. The significant increase in deposition rates over the last century is probably attributable to recent warming, implying a potential utilization of radionuclides as environmental indicators in this region.

Keywords: radionuclides; ${ }^{210} \mathrm{~Pb}$ dating; ${ }^{210} \mathrm{~Pb}$ and ${ }^{137} \mathrm{Cs}$ flux; ornithogenic sediments; warming; the Ross Sea region 


\section{Introduction}

The radiometric dating method on shorter time scales (less than 200 yrs ago) using the natural fallout radionuclide ${ }^{210} \mathrm{~Pb}$ was initially introduced by Goldberg (1963), but it was not widely used until after its first application to lake sediments by Krishnaswami et al. (1971). Later with the development of calculation models of Constant Initial Concentration (CIC, for uniform accumulation rate) and Constant Rate of Supply (CRS, for non-uniform accumulation rate), and corroboration from artificial fallout radionuclides including ${ }^{137} \mathrm{Cs}$ and ${ }^{241} \mathrm{Am}$ for accurate age calibration (Appleby and Oldfield, 1978), the dating method broadened its usage into different geo-carriers such as lake, estuarine and marine sediments, and peat bogs (Appleby, 2008). After decades of application, ${ }^{210} \mathrm{~Pb}$ dating has been recognized as one of the most important dating techniques in various paleo studies.

So far, studies on natural and artificial fallout radionuclides in Antarctica serve diverse purposes besides dating. For example, analyses of natural and artificial radionuclides on different materials including ice, sediments, soils, seawater, and biological samples play important roles in establishing baselines from which to estimate the possible impacts of radioactive pollution, to understand marine dynamic processes, and to examine the impacts of anthropogenic activities on this remote area (Schüller et al., 2004; Sanders et al., 2010). Radionuclides in aqueous systems may function as tracers for investigating water circulation and sedimentary processes due to their distinctly different geochemical behaviors (Godoy et al., 1998). Historical records of radionuclides have been used to study the long range water and atmospheric transportation of anthropogenic substances, and for exploring mineral resources (Jia et al., 2000). Snow-firn-ice dynamics based on ${ }^{210} \mathrm{~Pb}$ deposition could grant insights into the balance of the Antarctic ice sheet (Goodwin, 1990; Gallée 2001).

Antarctica developed its own unique ecosystem structures due to its isolation from other continents and the absence of anthropogenic influence (Jenouvrier et al., 2005). Its specific location and fragile ecosystems make this land extremely sensitive to climate change (Clarke et al, 2007). In the coastal ice-free areas scattered around Antarctica where migrating birds have the most impact, continuous and well-preserved ornithogenic sediments were formed, and serve as a natural archive for both geochemical dynamics and paleo-environmental conditions, allowing studies on climate change and the corresponding ecological responses in the past, which, in turn, 
is essential in understanding current and future trends of global warming and its impact on local ecosystems (Parmesan, 2006; McClintock et al., 2008). The Ross Sea is a high latitude embayment with a long history of Adélie penguin (Pygoscelis adeliae) occupation (Emslie et al., 2007). Our previous studies focused mainly on the geochemical features and processes based on heavy metal mercury, bio-element assemblage, stable isotope $\delta^{13} \mathrm{C}$ and $\delta^{15} \mathrm{~N}$, and rare earth elements in the ornithogenic sediments from this region (Nie et al., 2015). To further decode the information of the past stored in the sediments, accurate chronology of these ornithogenic sediments is crucially required.

In this study, we analyzed the levels of radionuclides including ${ }^{210} \mathrm{~Pb},{ }^{226} \mathrm{Ra}$ and ${ }^{137} \mathrm{Cs}$ in eight ornithogenic sediment profiles collected from the ice-free areas in McMurdo Sound of the Ross Sea region for the first time. Since no data on radionuclides on a similar geo-carrier was ever reported in this area, we wished to determine whether the sediments with heavy avian influence could be used for ${ }^{210} \mathrm{~Pb}$ dating, and exploit the potential of the radionuclides as indicators for environment change.

\section{Material and methods}

\subsection{Study area}

Ornithogenic sediments used in this study were collected in ice-free areas of the southern Ross Sea region in January 2010 (Fig. 1). This region is highly sensitive to climate change as it is located at the conjunction of three different air masses from Victoria Land, the Ross Sea, and the Ross Ice Shelf. The weather here is capricious and severe: the mean annual temperature is $-18^{\circ} \mathrm{C}$, and the temperature may reach $8{ }^{\circ} \mathrm{C}$ in summer and $-50{ }^{\circ} \mathrm{C}$ in winter. The average wind speed is 22.8 $\mathrm{Km} / \mathrm{h}$, but may exceed $190 \mathrm{Km} / \mathrm{h}$ on occasion. Ross Island $\left(\sim 2460 \mathrm{~km}^{2}\right)$ is of volcanic origin in McMurdo Sound comprising four volcanoes: Mts Terror (elevation: 3262 m,), Terra Nova (2130 m), Erebus (3794 m), and Bird (1800 m), with glacial ice mantles inland, leaving three ice-free areas where Adélie penguins currently breed at Cape Crozier $\left(\sim 18 \mathrm{~km}^{2}\right)$, Cape Bird $\left(\sim 15 \mathrm{~km}^{2}\right)$, and Cape Royds $\left(\sim 13 \mathrm{~km}^{2}\right)$. Beaufort Island $\left(\sim 18.4 \mathrm{~km}^{2}\right)$ is $21 \mathrm{~km}$ north of Ross Island with Adélie penguins breeding on the ice-free areas on the eastern and southern coasts. A long history of penguin occupation has left these areas with numerous abandoned penguin colonies as well as active ones, allowing the study of penguin paleoecology. Surface run-offs are observed in summers, and 
with the input of nutrients from penguin guano, freshwater algae are widely distributed in the ponds and catchments near the colonies.

\subsection{Sample collection}

The sampling sites are located in several separate areas on Ross and Beaufort Islands (Fig. 1). Details on depth, location, lithology (see also Fig. 1 in appendix) and catchment description of the eight profiles are provided in Table 1. The site MB4 is close to abandoned penguin colonies in mid Cape Bird. MB4 was collected in a small pond between the fourth and fifth raised beach ridge. According to field observations, the sediment layer below $15 \mathrm{~cm}$ was comprised of fine-grained ornithogenic sediments with a dark color and rancid smell; the sediment unit between 5 and 15 $\mathrm{cm}$ was mainly composed of dark-colored coarse sands; the surface layer is rich in fine black algae residue. Right next to MB4, profile CL2 was taken from the northern edge of a pond located on the fifth beach ridge above sea level. CL2 mostly consisted of fairly homogeneous black and grey colored silts, and its uppermost part was comprised of dark green fresh-water algae residues. Profile MB6 was collected from a small catchment on the second terrace above sea level in an active penguin colony on the north side of Cape Bird. The sediments below $24 \mathrm{~cm}$ were dark-colored ornithogenic soils, and the remainder consisted of brown clay. Seal hairs were found in the sediment layer beneath $32 \mathrm{~cm}$. Profile MB1 with relatively homogeneous lithology was collected from a dried-out catchment on an elevated hillside south of MB4 with traces of penguin activities (bones and feather discovered). Profile CC was collected from a fecal pit in Cape Crozier, Ross Island. Large amounts of penguin guano was deposited here, together with eggshells and downy feathers. The biological remains were concentrated in the layer above $7 \mathrm{~cm}$. Profile MR1 and MR2 were collected near the active penguin colonies at Cape Royds. From bottom to top, both profiles changed from dark-colored weathering products to red-colored ornithogenic sediments with gravels at critical depths of 12 and $15 \mathrm{~cm}$, respectively. Profile BI was excavated from a small peat near the modern penguin colony on the southwest side of Beaufort Island. From the bottom to top, brown clay gradually transitions into black fine-grained ornithogenic sediments. Profile MB4, MB6, MB1, MR1 and MR2 were directly taken in dug pits and sectioned in the field (intervals: $0.8 \mathrm{~cm}$ for MB4; $0.6 \mathrm{~cm}$ for MB6; $1 \mathrm{~cm}$ for MB1, $1 \mathrm{~cm}$ for layer above $15 \mathrm{~cm}$, $2 \mathrm{~cm}$ for layer below $15 \mathrm{~cm}$ in MR1; $1 \mathrm{~cm}$ for layer above $15 \mathrm{~cm}, 2 \mathrm{~cm}$ for layer below $15 \mathrm{~cm}$, and 
the remaining sediments were divided into 2 subsamples in MR2), while CC, BI and CL2 were collected using sediment cores and transported back to the lab and sectioned at the intervals of $0.5 \mathrm{~cm}$. All sediment samples were air dried and homogenized by grinding before radionuclide and chemical analyses. More details about sampling has been reported in Nie et al. (2012, 2015).

\subsection{Analytical methods}

The radioactivity of sediment samples was measured by direct gamma spectrometry (Ortec HPGe GWL series, well-type, coaxial, low background, intrinsic germanium detector, AMETEK Company). The detector was protected by a $2 \mathrm{~mm}$ inner copper wall and a $10 \mathrm{~cm}$ outer lead chamber (connected to a liquid nitrogen tank for thermal stability) to avoid possible interference of background radiation. The standard radionuclide samples (soil samples) were provided and calibrated by China Institute of Atomic Energy (isotopes for calibration: ${ }^{210} \mathrm{~Pb},{ }^{226} \mathrm{Ra},{ }^{137} \mathrm{Cs},{ }^{241} \mathrm{Am}$, ${ }^{155} \mathrm{Eu},{ }^{57} \mathrm{Co},{ }^{54} \mathrm{Mn},{ }^{65} \mathrm{Zn}$ and $\left.{ }^{60} \mathrm{Co}\right)$. Homogenized sediment samples were dried at $105{ }^{\circ} \mathrm{C}$ to constant weight and sealed into $5 \mathrm{ml}$ centrifuge tubes for a storage of about 3 weeks to reach radioactive equilibration between ${ }^{226} \mathrm{Ra}$ and its daughter nuclide ${ }^{214} \mathrm{~Pb}$. Spectra were obtained after about $24 \mathrm{~h}$ to record sufficient counts. Activity of ${ }^{210} \mathrm{~Pb}$ was measured by its peak at 46.5 $\mathrm{keV}$ in the resulting spectrum files. The ${ }^{226} \mathrm{Ra}$ activity was determined by its daughter isotope ${ }^{214} \mathrm{~Pb}$ at $295 \mathrm{keV}$, and ${ }^{137} \mathrm{Cs}$ was measured by its emissions at $662 \mathrm{keV}$. Further details on this methodology can be found in Xu et al., 2010.

\section{Results and discussion}

\subsection{Radionuclide distribution and chronology determination}

${ }^{210} \mathrm{~Pb}$ (half-life $\mathrm{T}_{1 / 2}=22.3 \mathrm{a}$ ) dating has been commonly used in lacustrine, marine and peat sediments based on the disequilibrium between ${ }^{210} \mathrm{~Pb}$ and its parent isotope ${ }^{226} \mathrm{Ra}$ in the ${ }^{238} \mathrm{U}$ decay series, since part of the intermediate gaseous isotope ${ }^{222} \mathrm{Rn}$ would escape from the lithosphere to the atmosphere and join the circulation of air masses (Doran et al., 1999, Appleby, 2008; Le Roux and Marshall, 2011). Short-lived ${ }^{222} \mathrm{Rn}\left(\mathrm{T}_{1 / 2}=3.8 \mathrm{~d}\right)$ then decays to ${ }^{210} \mathrm{~Pb}$ and returns to the surface through wet and dry deposition. Local ${ }^{210} \mathrm{~Pb}$ defined as supported ${ }^{210} \mathrm{~Pb}$ is at equilibrium with ${ }^{226} \mathrm{Ra}$, while precipitated ${ }^{210} \mathrm{~Pb}$ defined as excess ${ }^{210} \mathrm{~Pb}\left({ }^{210} \mathrm{~Pb}\right.$ ex $)$ causes disequilibrium between ${ }^{226} \mathrm{Ra}$ and total ${ }^{210} \mathrm{~Pb}$. Since the decay of ${ }^{210} \mathrm{~Pb}$ ex follows the radioactive 
decay law, time sequence of the upper layer sediments could thus be inferred from the half-life and concentration-versus-depth profiles of ${ }^{210} \mathrm{~Pb}$ (Godoy et al., 1998).

Activity of radionuclides including ${ }^{210} \mathrm{~Pb},{ }^{226} \mathrm{Ra},{ }^{137} \mathrm{Cs}$ in all eight profiles and the corresponding dry bulk density for each depth in the upper layers of MB4, MB6, MB1 and CC are given in Table 2. Nuclide data in profile MB4, MB6, CL2 and MB1 are concisely presented in the supplementary material of our previous study on the paleoecology (Nie et al., 2015), and here we discuss these data altogether with CC, MR1, MR2 and $\mathrm{BI} .{ }^{210} \mathrm{~Pb}$ and ${ }^{226} \mathrm{Ra}$ activities varied significantly among sites with the coefficient of variation for both nuclides around $40 \%$. Since ${ }^{210} \mathrm{~Pb}$ was generally declining due to the decay of ${ }^{210} \mathrm{~Pb}_{\mathrm{ex}}$ and ${ }^{226} \mathrm{Ra}$ less fluctuating (Fig. 2), the difference of ${ }^{226} \mathrm{Ra}$ among profiles was more obvious. We tested the correlation between ${ }^{226} \mathrm{Ra}$ and grain size (median diameter) in MB4, MB6 CL2 and $\mathrm{BI}$, and find it insignificant (data not shown). And finer sediments don't necessarily correspond to higher ${ }^{226} \mathrm{Ra}$ level (much lower median diameter in upper MB6 has similar ${ }^{226}$ Ra level to CL2 with coarser grain size). Thus we believe ${ }^{226} \mathrm{Ra}$ was mainly determined by the lithological property of the bedrock that the sediments originally derived from. ${ }^{210} \mathrm{~Pb}$ in $\mathrm{MB} 4$ was fluctuating with an overall monotonic decreasing trend, and met the slightly ascending ${ }^{226} \mathrm{Ra}$ at $8 \mathrm{~cm}$ (with the ${ }^{210} \mathrm{~Pb}_{\mathrm{ex}}$ of more than 3 following subsamples around or below 0 for all eight profiles). Both ${ }^{210} \mathrm{~Pb}$ and ${ }^{226} \mathrm{Ra}$ in $\mathrm{MB} 6$ formed a high value plateau from 2.4 to $3.6 \mathrm{~cm}$, interrupting their decreasing trends. ${ }^{226} \mathrm{Ra}$ started to increase below the plateau while ${ }^{210} \mathrm{~Pb}$ dropped at $4.8 \mathrm{~cm}$, and ${ }^{210} \mathrm{~Pb}_{\mathrm{ex}}$ reduced to its zero point at $5.4 \mathrm{~cm} .{ }^{210} \mathrm{~Pb}$ kept decreasing from the surface, but increased below $3.5 \mathrm{~cm}$ in CL2 . Both ${ }^{210} \mathrm{~Pb}$ and the stable ${ }^{226} \mathrm{Ra}$ started to decline below $5 \mathrm{~cm}$ with the equilibrium reached at 7 $\mathrm{cm} .{ }^{210} \mathrm{~Pb}$ in MB1 decreased sharply from surface to $3 \mathrm{~cm}$ in depth, then rose to a peak at $5 \mathrm{~cm}$ and went down gradually from there. ${ }^{226}$ Ra in MB1 increased slowly but steadily, except for a minor drop at $4 \mathrm{~cm}$, and the equilibration was reached at $9 \mathrm{~cm}$. Both ${ }^{210} \mathrm{~Pb}$ and ${ }^{226} \mathrm{Ra}$ in profile $\mathrm{CC}$ reached their maximum at $1 \mathrm{~cm}$, and then declined and met their equilibrium at $5 \mathrm{~cm}$. Besides the general descent in ${ }^{210} \mathrm{~Pb}$ trends, both MR1 and MR2 showed a drop at $6 \mathrm{~cm}$ (more sudden in MR2), while ${ }^{226} \mathrm{Ra}$ was stable in the two profiles with their ${ }^{210} \mathrm{~Pb}_{\text {ex }}$ zero points at $10 \mathrm{~cm}$. The smoothly decreasing ${ }^{210} \mathrm{~Pb}$ in $\mathrm{BI}$ was disturbed by a minor peak at $3.5 \mathrm{~cm}$, which was also observed in ${ }^{226} \mathrm{Ra}$ with the equilibrium reached right after at $4 \mathrm{~cm}$.

Based on our field records and previous research on the geochemistry (Liu et al., 2013), the 
sediments are heavily impacted by avian activities. The organic matter (OM) consisted primarily of penguin guano and guano-nourished fresh-water algae, which might influence the nuclide in the surface layers. With this extra characteristic to normal lacustrine sediments, we need to determine the effect of $\mathrm{OM}$ on ${ }^{210} \mathrm{~Pb}_{\mathrm{ex}}$ before age calculation. For all the profiles, guano and algae constitute the majority of total organic carbon (TOC), and phosphorus (P) serves as a robust marker for impact from penguin guano. To determine the extent of influence from guano and algae on ${ }^{210} \mathrm{~Pb}_{\mathrm{ex}}$ distributions in the sediments, we analyzed the respective correlation of TOC and $\mathrm{P}$ with ${ }^{210} \mathrm{~Pb}_{\mathrm{ex}}$. As can be seen in Table 3, there was little consistency in statistics with only MB4 and $\mathrm{BI}$ showing slight or moderate relationships to ${ }^{210} \mathrm{~Pb}_{\mathrm{ex}}-\mathrm{TOC}$ and/or ${ }^{210} \mathrm{~Pb}_{\mathrm{ex}}-\mathrm{P}$, while the relationships in the other profiles were insignificant, indicating that OM cannot be a controlling factor for the distribution of ${ }^{210} \mathrm{~Pb}_{\mathrm{ex}}$ in the bulk sediments. According to a previous study on the ornithogenic sediments from Xisha Islands, guano has much lower ${ }^{210} \mathrm{~Pb}$ activity compared to the sediments, and nor do guano input exert much influence on the vertical distribution of ${ }^{210} \mathrm{~Pb}_{\mathrm{ex}}$ (Xu et al., 2010). Similarly, ${ }^{210} \mathrm{~Pb}$ activity in fresh guano and algae samples collected near the sediment profiles from the Ross Sea region were very low $\left({ }^{210} \mathrm{~Pb}_{\text {guano }}=9.37 \pm 4.22, \mathrm{n}=2 ;{ }^{210} \mathrm{~Pb}_{\text {algae }}=15.18 \pm 2.63, \mathrm{n}=2\right)$. Considering the proportion of TOC in the profiles was usually around $5 \%$ or less (Liu et al., 2013), OM with low ${ }^{210} \mathrm{~Pb}$ activity cannot be a source of ${ }^{210} \mathrm{~Pb}_{\mathrm{ex}}$. As a function of nuclide activities of individual samples from depths, ${ }^{210} \mathrm{~Pb}_{\mathrm{ex}}$ flux stands for a proxy for ${ }^{210} \mathrm{~Pb}_{\mathrm{ex}}$ level. We listed ${ }^{210} \mathrm{~Pb}_{\mathrm{ex}}$ flux in the sediments from several different sites around Antarctica in Table 5. According to the comparison, ${ }^{210} \mathrm{~Pb}_{\text {ex }}$ level in the ornithogenic sediments in our study was similar to that of Signy Island (ornithogenic), but higher than the lacustrine sediments unaffected by seabirds from McMurdo Dry Valley and South Shetland. Thus we believe that guano and algae-derived organic matter may still act as an adsorbent and help in retaining the atmospherically deposited ${ }^{210} \mathrm{~Pb}$ in the penguin-affected sediments. To sum up, the weak correlation ${ }^{210} \mathrm{~Pb}_{\mathrm{ex}}$ showed with TOC and $\mathrm{P}$ for most of the eight profiles and the low ${ }^{210} \mathrm{~Pb}$ activity in fresh guano and algae samples ruled out the possibility of guano or algae exerting heavy influence over the distribution of ${ }^{210} \mathrm{~Pb}_{\mathrm{ex}}$. Alternatively, we suggest that ${ }^{210} \mathrm{~Pb}$ in the sediments from this region was mainly controlled by atmospheric precipitation instead of OM, though OM does play a role in retaining ${ }^{210} \mathrm{~Pb}$ in the sediments. 
As shown in Fig. 2, ${ }^{210} \mathrm{~Pb}$ in the measured profiles generally declined with depth, but not exponentially, probably attributed to the varying accumulation rate. With atmospheric fallout determined as the source of ${ }^{210} \mathrm{~Pb}_{\mathrm{ex}}$, the Constant Rate of Supply (CRS) model was applied for dating calculations (Appleby, 2000; Appleby, 2008). The results of ${ }^{210} \mathrm{~Pb}$ dating for all the profiles are plotted in Fig.2. Accordingly, $6.4 \mathrm{~cm}$ in MB4, 4.2cm in MB6, $6.5 \mathrm{~cm}$ in $\mathrm{CL2}, 8 \mathrm{~cm}$ in $M B 1,4.5 \mathrm{~cm}$ in CC, $9 \mathrm{~cm}$ in MR1/MR2 and $3.5 \mathrm{~cm}$ in Bl dated to 149,119,170,135, 117, 151, 108 and 162 a, respectively.

${ }^{137} \mathrm{Cs}\left(\mathrm{T}_{1 / 2}=30.2 \mathrm{a}\right)$ is a radionuclide that originates solely from anthropogenic activities including nuclear/thermonuclear explosions (from 1950 1980s) and nuclear power plant accidents, which have occurred mainly in the Northern Hemisphere (Giuliani et al., 2003; Gulin and Stokozov, 2005). Though radioactive fallout tends to remain in the same hemisphere where it was produced, a small fraction of ${ }^{137} \mathrm{Cs}$ may still manage to slowly migrate to polar regions via global atmospheric circulation. The transit time for tropospheric transport of air masses from a distant continent to Antarctica is approximately 30 days (Maenhaut et al., 1979; UNSCEAR, 1982; Pourchet et al., 2003). Due to the precise time points marked by the nuclear tests and nuclear power plant accidents, deposited ${ }^{137} \mathrm{Cs}$ usually shows elevated activity in the corresponding layers, and thus can be used as a chronological marker to assist in the calibration of ${ }^{210} \mathrm{~Pb}$ dates (Koide et al., 1979; Arnaud et al., 2006). The radionuclide was detected in most profiles, but the signal was generally weak (several Bq/kg, Table 2) except in profile MB1. From surface layer to $4.8 \mathrm{~cm}$ in depth, ${ }^{137} \mathrm{Cs}$ in MB4 formed a peak with its maximum $6.6 \mathrm{~Bq} / \mathrm{kg}$ at $2.4 \mathrm{~cm}$. Throughout the profile MB6, only sediment sample at $1.2 \mathrm{~cm}$ showed ${ }^{137} \mathrm{Cs}$ activity of $3.6 \mathrm{~Bq} / \mathrm{kg} .{ }^{137} \mathrm{Cs}$ in CL2 was about 3 $\mathrm{Bq} / \mathrm{kg}$ above $1 \mathrm{~cm}$, then it declined to about $1 \mathrm{~Bq} / \mathrm{kg}$ from 1 to $2.5 \mathrm{~cm}$, and below which was undetectable. ${ }^{137} \mathrm{Cs}$ in MB1 dropped from $16.6 \mathrm{~Bq} / \mathrm{kg}$ at $1 \mathrm{~cm}$ to $1.4 \mathrm{~Bq} / \mathrm{kg}$ at $4 \mathrm{~cm}$, and was not detected in the remaining section. All samples from CC and MR2 was below detection limit, while ${ }^{137} \mathrm{Cs}$ in MR2 fluctuate around $2 \mathrm{~Bq} / \mathrm{kg}$ above $6 \mathrm{~cm}$ before dropping to $0 \mathrm{~Bq} / \mathrm{kg}$. ${ }^{137} \mathrm{Cs}$ in $\mathrm{BI}$ kept decreasing from the surface with depth, but formed a peak at the same level as the surface at 2 $\mathrm{cm}$. The ${ }^{137} \mathrm{Cs}$ peak in MB4 was rather apparent at 1988, but judging from the fact that no signal of the Chernobyl nuclear plant accident has been detected in Antarctica, it's probably just the result of the high mobility of ${ }^{137} \mathrm{Cs}$ (de Lima Ferreira et al., 2013). ${ }^{137} \mathrm{Cs}$ in MR2 and CC was too low to function as a chronological marker, while its peaks in MB6, CL2, MR1 and $B$ I were in 
discrepancy with ${ }^{210} \mathrm{~Pb}$ age. This result may be explained by the following processes. First, the activity of the nuclide ${ }^{137} \mathrm{Cs}$ was greatly decreased due to the long distance transportation in the atmosphere. Very low levels of radioactivity in the sediments would weaken its function as a reference time marker. Second, the radionuclide ${ }^{137} \mathrm{Cs}$ is chemically active and has a relatively high mobility. Thus, downward diffusion might occur (Schüller et al., 2004; de Lima Ferreira et al., 2013). The surface layer in MB1 showed evident ${ }^{137} C$ s activity peaks, suggesting the local environment may impose a higher influence on the nuclide than precipitation (Schüller et al., 2004). ${ }^{210} \mathrm{~Pb}$ dating in the Ross Sea region is relatively limited, however, analyzed nuclides from the ornithogenic sediments in this study produced sufficient data for ${ }^{210} \mathrm{~Pb}$ dating. Due to the distant location of the sampling site, neither disturbance from human activities nor local animals were observed during field work. Further chronology determination using $A M{ }^{14} \mathrm{C}$ dating based on biological remains including penguin bones/feathers and seal hairs showed no age inversion (Nie et al., 2015), reassuring the preservation of the sediments. Thus the reliability of ${ }^{210} \mathrm{~Pb}$ dating of the ornithogenic sediments in the Ross Sea region can be validated.

\subsection{Environmental implications of Radionuclide flux in the Ross Sea region}

Fluxes of ${ }^{210} \mathrm{~Pb}_{\text {ex }}$ and ${ }^{137} \mathrm{Cs}$ in the profiles were calculated based on their inventories $\left(\mathrm{I}_{\mathrm{s}}\right)$, which were in turn calculated from radioactivity and dry bulk density (measured only in MB4, MB6, MB1 and CC; Table 4) using the equations:

$$
\begin{aligned}
& I_{m}=A \times \rho \times d \\
& \text { flux }=I_{s} \times \lambda
\end{aligned}
$$

$I_{m}\left(B q / m^{2}\right)$ was the individual inventory of the subsample at depth $m$ calculated multiplying activity per weight unit $(\mathrm{A}: \mathrm{Bq} / \mathrm{Kg})$ by bulk density $\left(\rho: \mathrm{g} / \mathrm{cm}^{3}\right)$ and the sectioning intervals $(\mathrm{d}: \mathrm{cm})$, and $I_{s}\left(B q / \mathrm{m}^{2}\right)$ was total inventory of the profile (the add-up of $\left.I_{m}\right)$. The decay constant of ${ }^{210} \mathrm{~Pb} \lambda$ $=0.031 \mathrm{a}^{-1}$, and the decay constant of ${ }^{137} \mathrm{Cs} \lambda=0.023 \mathrm{a}^{-1}$. The result indicates ${ }^{210} \mathrm{~Pb}_{\mathrm{ex}}$ flux varying from 20.67 to $87.24 \mathrm{~Bq} / \mathrm{m}^{2} \mathrm{a}$, and ${ }^{137} \mathrm{Cs}$ flux varying from 0.64 to $10.09 \mathrm{~Bq} / \mathrm{m}^{2} \mathrm{a}$ (Table 4). Comparing to multiple ${ }^{210} \mathrm{~Pb}_{\text {ex }}$ flux determined on different sources across Antarctica (Table 5), our results are similar to lacustrine sediments from Signy Island, since the profiles were developed in lacustrine or similar environments like the catchments near the penguin colonies. But ${ }^{210} \mathrm{~Pb}_{\mathrm{ex}}$ flux in the ornithogenic sediments was much greater than in some Antarctic lakes 
(only slightly higher than the value of direct fallouts from atmospheric precipitation, Table 5), which was probably caused by their limited catchment size. The calculated ${ }^{210} \mathrm{~Pb}_{\text {ex }}$ and ${ }^{137} \mathrm{Cs}$ fluxes for the profiles MB1, MB4, MB6 and CC are given in Fig. 3. There is an evident difference among the profiles with the maximum more than $4 x$ higher than the minimum ${ }^{210} \mathrm{~Pb}_{\mathrm{ex}}$ flux and $15 \mathrm{x}$ higher in ${ }^{137} \mathrm{Cs}$ (profile $\mathrm{CC}$ not included), and we found the inventory and flux in ${ }^{210} \mathrm{~Pb}_{\mathrm{ex}}$ and ${ }^{137} \mathrm{Cs}$ decreased in the order of MB1 $>$ MB4 $>$ MB6 $>C C$.

Since ${ }^{210} \mathrm{~Pb}_{\mathrm{ex}}$ and ${ }^{137} \mathrm{Cs}$ were both atmosphere-derived, precipitated nuclides fluxes should have a regional consistency (Godoy et al., 1998; Pourchet et al., 2003). However, the fluxes of the profiles varied significantly across Ross Island, implying a different mechanism. Thus the large difference in observed fluxes could only be caused by the individual sedimentary environment of each profile. A much lower average ${ }^{210} \mathrm{~Pb}_{\mathrm{ex}}$ flux of 5.5 and $3.5 \mathrm{~Bq} / \mathrm{m}^{2} \mathrm{a}$, in Antarctica was calculated based on the ${ }^{210} \mathrm{~Pb}$ concentration in the surface snow and annual mean precipitation (Preiss et al., 1996, Appleby, 2008, Table 5). This flux was more than one order of magnitude lower than the levels in the mid-latitude sites in the Northern Hemisphere, and was in accordance with the simulated results from modeling (Henderson and Maier-Reimer, 2002). As mentioned above, ${ }^{210} \mathrm{~Pb}_{\mathrm{ex}}$ flux in the lacustrine sediments affected by seabirds at Signy Island, Antarctica, was higher than the estimated atmosphere flux (Appleby et al., 1995, Table 5). The phenomenon of amplified sedimentary ${ }^{210} \mathrm{~Pb}$ flux was believed to be induced by a concentrated ${ }^{210} \mathrm{~Pb}$ from the catchment loads from inflows during the austral spring thaw (Appleby, 2008; Sanders et al., 2010). According to field records (Table 1), MB4 was collected from a lacustrine environment, which receives precipitated ${ }^{210} \mathrm{~Pb}$ from the entire catchment. MB1 consisted of dry sediments, but judging from the surrounding terrain, this site should be within or near an aquatic environment. In contrast, MB6 and CC were directly excavated from active penguin colonies with much less inflow than the two profiles mentioned above. Thus, the lower ${ }^{210} \mathrm{~Pb}_{\text {ex }}$ fluxes in MB6 and $\mathrm{CC}$ are understandable. However, profile MB1 with its smaller catchment size and lower moisture level than MB4 exhibited higher ${ }^{210} \mathrm{~Pb}_{\mathrm{ex}}$ and ${ }^{137} \mathrm{Cs}$ fluxes in the sediments. This cannot simply be explained by the difference of the depositional environment, for the ${ }^{137} \mathrm{Cs}$ flux in MB1 was more than twice as much as in MB4.

To explore the reason behind this, we plotted ${ }^{210} \mathrm{~Pb}_{\mathrm{ex}}$ and ${ }^{137} \mathrm{Cs}$ flux data of MB1, MB4, MB6 and CC from Ross Island with their average deposition rate (Fig. 3). Combined with the 
distribution of the sampling sites shown in Fig. 1, the decreasing order of deposition rate from MB1 to CC indicates that the extra nuclides in profile MB1 were highly relevant to its location. Due to the low rain/snow fall in Antarctica ( $202.5 \mathrm{~mm}$ in McMurdo Sound), melt water from accumulated snow in the glacier front becomes the most important supply for the ponds and catchments scattered in the ice-free areas, ensuring the prosperity of the local ecosystem (Kennedy, 1993; Archer et al., 2015). Precipitated ${ }^{210} \mathrm{~Pb}$ and ${ }^{137} \mathrm{Cs}$ would be trapped in the permanent ice cover with continuously formed new snow, and partly carried away by the flows of melt water during the thaw in the austral spring (Pourchet et al., 2003; Suzuki et al., 2004). The ice-free area of Cape Bird extends from the coast up to the western margin of Mt Bird ice cap which feeds several outlet glaciers that flow around parasitic cinder cones and terminate on land (Dochat et al., 2000). Judging from the geographic feature in Cape Bird and field records, surface runoff from the scattered glacier ice and snow banks in front of Mt Bird ice cap would make their paths from the elevated hillside through raised beach ridges and finally to the sea shore (Fig. 1). Thus MB1 profile which was closer to the glacial front would receive more inflow, and it was clearly corroborated by its elevated average deposition rate (as high as $0.12 \mathrm{~g} / \mathrm{cm}^{2}$ a; Fig. 3). MB4 with a larger catchment but farther away from the glacial front, however, has a lower deposition rate, which in turn resulted in lower ${ }^{210} \mathrm{~Pb}_{\mathrm{ex}}$ and ${ }^{137} \mathrm{Cs}$ flux, not to mention $\mathrm{MB} 6$ and $\mathrm{CC}$ with even smaller catchment sizes and deposition rate. Since the chemical activity and mobility of Cs were much higher than $\mathrm{Pb}$, its downward movement was more significant, resulting in a more drastic decrease from profiles with high to low deposition rates (Ivanovich and Harmon, 1992; Mietelski et al., 2008).

Apart from the different fluxes among profiles, high ${ }^{210} \mathrm{~Pb}_{\text {ex }}$ and ${ }^{137} \mathrm{Cs}$ flux in the site closest to the glacial front may also indicate an increased input of melt water caused by continuous warming over the recent century (Appleby et al., 1995; Gulin and Stokozov, 2005; Sanders et al., 2010). To verify the hypothesis, we plotted the deposition rate of the four profiles against age sequence (Fig. 4). As is shown in this figure, the deposition rate of all profiles showed constant ascending trends toward the present, except for the sudden drop in the surface layer in MB1. The curves were rather low and stable before $1960 \sim 1970$ s, and began to rise rapidly thereafter. The most recent one or two decades witnessed the highest deposition rate in this region. According to the report of PAGES $2 \mathrm{k}$ Consortium, synthetic temperature reconstructions using different data 
sources exhibit a clear warming trend after the little ice age (LIA) in Antarctica. Rhodes et al. (2012) reported that the Ross Sea region was $1.6 \pm 1.4{ }^{\circ} \mathrm{C}$ warmer in the post-LIA period than the LIA based on the analyses of $\delta D$ from an ice core from Mt Erebus (Ross Island) in the Ross Sea region. Similarly, Bertler et al. (2011) reported their isotopic analysis on an ice core retrieved from the Victoria Lower Glacier, showing the surface temperatures in the Ross Sea region increased about $2{ }^{\circ} \mathrm{C}$ after the LIA. According to the instrumentally recorded meteorological data from Scott Base on Ross Island, there has been a significant spring warming of $0.41 \pm 0.39{ }^{\circ} \mathrm{C}$ per decade since 1958 , and this trend increased to $0.64 \pm 0.69{ }^{\circ} \mathrm{C}$ per decade after 1979 (Clark et al., 1988; Schneider et al. 2011; Sinclair et al., 2012). This warming also has been corroborated by the increasing resident Adélie penguin population and the southward expansion of their colonies since the 1970s (Taylor and Wilson, 1990). There is no doubt that the warming in this region would produce more melt water, increase the surface flow carrying the nuclides accumulated in the ice, snow and soil detritus. As our cores were sampled along the runoff pathway, and they have different accumulation rates, this would enhance the difference of the inventories and fluxes of ${ }^{210} \mathrm{~Pb}_{\mathrm{ex}}$ and ${ }^{137} \mathrm{Cs}$ among the profiles (Sanders et al., 2010). Nonetheless, the evident rise of sedimentation rate and flux throughout all sediment profiles is a sound indicator of successive warming over the past century. Thus, it is made clear that nuclides in the ornithogenic sediments from the Ross Sea region can be used not only in chronological determinations, but also as indicators for local climate changes.

\section{Conclusion}

Based on the analyses of radionuclides including ${ }^{210} \mathrm{~Pb},{ }^{226} \mathrm{Ra}$ and ${ }^{137} \mathrm{Cs}$, age sequences from eight ornithogenic sediment profiles were successfully obtained using the CRS model, verifying the reliability of ${ }^{210} \mathrm{~Pb}$ dating on this type of geo-carrier heavily influenced by biological activities in the Ross Sea region. The difference of ${ }^{210} \mathrm{~Pb}_{\mathrm{ex}}$ and ${ }^{137} \mathrm{Cs}$ flux among four profiles were found to be influenced by their individual depositional environments. The decreasing flux from MB1 to CC was induced by the different average deposition rate of the sediments, which was related to the specific location of the profiles. The rising deposition rate against age revealed in all four profiles indicated increased runoff of melt water carrying ${ }^{210} \mathrm{~Pb}$ and ${ }^{137} \mathrm{Cs}$ from accumulated snow, as well as soil detritus, in the warming environment of the last century (especially after the 1970s), 
which implies the potential of radionuclides as environmental indicators in this region.

Acknowledgements We would like to thank the Chinese Arctic and Antarctic Administration of the State Oceanic Administration for project support. We also thank the United States Antarctic Program (USAP), Raytheon Polar Services, and in particular J. Smykla, E. Gruber and L. Coats for their valuable assistance in the field. This study was supported by the National Natural Science Foundation of China (Grant Nos. 41576183 and 41376124) and NSF Grant ANT 0739575.

\section{References}

Appleby, P. G. (2008). Three decades of dating recent sediments by fallout radionuclides: a review. The Holocene, 18(1), 83-93.

Appleby, P. G. (2000). Radiometric dating of sediment records in European mountain lakes. Journal of Limnology, 59(1s), 1-14.

Appleby, P. G., Oldfield, F. (1978). The calculation of ${ }^{210} \mathrm{~Pb}$ dates assuming a constant rate of supply of unsupported'IOPb to the sediments. Catena, 51-18.

Appleby, P. G., Jones, V. J., Ellis-Evans, J. C. (1995). Radiometric dating of lake sediments from Signy Island (maritime Antarctic): evidence of recent climatic change. Journal of Paleolimnology, 13(2), 179-191.

Archer, S. D. J., McDonald, I. R., Herbold, C. W., Lee, C. K., Cary, C. S. (2015). Benthic microbial communities of coastal terrestrial and ice shelf Antarctic meltwater ponds. Frontiers in Microbiology, 6, 485.

Arnaud, F., Magand, O., Chapron, E., Bertrand, S., Boës, X., Charlet, F., Mélières, M. A. (2006). Radionuclide dating $\left({ }^{210} \mathrm{~Pb},{ }^{137} \mathrm{Cs},{ }^{241} \mathrm{Am}\right)$ of recent lake sediments in a highly active geodynamic setting (Lakes Puyehue and Icalma-Chilean Lake District). Science of the Total Environment, 366(2), 837-850.

Bertler, N., Mayewski, P. A., Carter, L. (2011). Cold conditions in Antarctica during the Little Ice Age-Implications for abrupt climate change mechanisms. Earth and Planetary Science Letters, 308(1), 41-51. 
Clarke, A., Holmes, L., White, M. (1988). The annual cycle of temperature, chlorophyll and major nutrients at Signy Island, South Orkney Islands, 1969-82. Br Antarct Surv Bull, 80, 65-86.

Clarke, A., Murphy, E. J., Meredith, M. P., King, J. C., Peck, L. S., Barnes, D. K., Smith, R. C. (2007). Climate change and the marine ecosystem of the western Antarctic Peninsula. Philosophical Transactions of the Royal Society B: Biological Sciences, 362(1477), 149-166.

de Lima Ferreira, P. A., Ribeiro, A. P., do Nascimento, M. G., de Castro Martins, C., de Mahiques, M. M., Montone, R. C., Figueira, R. C. L. (2013). ${ }^{137}$ Cs in marine sediments of Admiralty Bay, King George Island, Antarctica. Science of the Total Environment, 443, 505-510.

Dochat, T. M., Marchant, D. R., Denton, G. H. (2000). Glacial geology of Cape Bird, Ross Island, Antarctica. Geografiska Annaler. Series A. Physical Geography, 237-247.

Doran, P. T., Berger, G., Lyons, W., Wharton, R., Davisson, M., Southon, J., Dibb, J. (1999). Dating quaternary lacustrine sediments in the McMurdo Dry Valleys, Antarctica. Palaeogeography, Palaeoclimatology, Palaeoecology, 147(3), 223-239.

Emslie, S. D., Coats, L., Licht, K. (2007). A 45,000 yr record of Adélie penguins and climate change in the Ross Sea, Antarctica. Geology, 35(1), 61-64.

Ferreira, P. A., França, E. J., Figueira, R. C. (2013). Model of diffusion-convection of ${ }^{137}$ Cs in marine sediments: a mathematical approach for the assessment of recent sedimentation rates. 2013 International Nuclear Atlantic Conference, Recife, PE, Brazil, November 24-29, 2013.

Gallée, H., Guyomarc'h, G., Brun, E. (2001). Impact of snow drift on the Antarctic ice sheet surface mass balance: possible sensitivity to snow-surface properties. Boundary-Layer Meteorology, 99(1), 1-19.

Giuliani, S., Triulz, C., \& Vaghi, M. (2003). Antropogenic radionuclides in plants, animals and their environments in Antarctica. Marine ecological journal, 2(2). p. 5-15

Godoy, J. M., Schuch, L. A., Nordemann, D. J. R., Reis, V. R. G., Ramalho, M., Recio, J. C., Brito R. R. A., Olech, M. A. (1998). ${ }^{137} \mathrm{Cs},{ }^{226,}{ }^{228} \mathrm{Ra},{ }^{210} \mathrm{~Pb}$ and ${ }^{40} \mathrm{~K}$ concentrations in Antarctic soil, sediment and selected moss and lichen samples. Journal of environmental radioactivity, $41(1), 33-45$.

Goldberg, E. D. (1963). Geochronology with ${ }^{210} \mathrm{~Pb}$. Radioactive dating, 121-131.

Goodwin, I. D. (1990). Snow accumulation and surface topography in the katabatic zone of Eastern Wilkes Land, Antarctica. Antarctic Science, 2(03), 235-242. 
Gulin, S. B., Stokozov, N. A. (2005). ${ }^{137}$ Cs concentrations in Atlantic and western Antarctic surface waters: results of the 7th Ukrainian Antarctic Expedition, 2002. Journal of environmental radioactivity, $83(1), 1-7$.

Henderson, G. M., Maier-Reimer, E. (2002). Advection and removal of ${ }^{210} \mathrm{~Pb}$ and stable $\mathrm{Pb}$ isotopes in the oceans: a general circulation model study. Geochimica et Cosmochimica Acta, 66(2), 257-272.

Ivanovich, M., Harmon, R. S. (1992). Uranium-series disequilibrium: applications to earth, marine, and environmental sciences. Journal of Environmental Radioactivity, 41(1), 33-45.

Jenouvrier, S., Barbraud, C., Weimerskirch, H. (2005). Long-term contrasted responses to climate of two Antarctic seabird species. Ecology, 86(11), 2889-2903.

Jia, G., Triulzi, C., Marzano, F. N., Belli, M., Vaghi, M. (2000). The fate of plutonium, ${ }^{241} \mathrm{Am},{ }^{90} \mathrm{Sr}$ and ${ }^{137} \mathrm{Cs}$ in the Antarctic ecosystem. Antarctic Science, 12(02), 141-148.

Kennedy, A. D. (1993). Water as a limiting factor in the Antarctic terrestrial environment: a biogeographical synthesis. Arctic and Alpine Research, 308-315.

Koide, M., Michel, R., Goldberg, E. D., Herron, M. M., Langway, C. C. (1979). Depositional history of artificial radionuclides in the Ross Ice Shelf, Antarctica. Earth and Planetary Science Letters, 44(2), 205-223.

Krishnaswamy, S., Lal, D., Martin, J., Meybeck, M. (1971). Geochronology of lake sediments. Earth and Planetary Science Letters, 11(1), 407-414.

Le Roux, G., Marshall, W. (2011). Constructing recent peat accumulation chronologies using atmospheric fall-out radionuclides. Mires and Peat, 7(1), e14.

Liu, X., Nie, Y., Sun, L., Emslie, S. D. (2013). Eco-environmental implications of elemental and carbon isotope distributions in ornithogenic sediments from the Ross Sea region, Antarctica. Geochimica et Cosmochimica Acta, 117, 99-114.

Maenhaut, W., Zoller, W. H., Coles, D. (1979). Radionuclides in the South Pole atmosphere. Journal of Geophysical Research: Oceans (1978-2012), 84(C6), 3131-3138.

McClintock, J., Ducklow, H., Fraser, W. (2008). Ecological responses to climate change on the Antarctic Peninsula. American Scientist, 96(4), 302-310. 
Mietelski, J., Olech, M., Sobiech-Matura, K., Howard, B., Gaca, P., Zwolak, M., Błażej S., Tomankiewicz, E. (2008). ${ }^{137} \mathrm{Cs},{ }^{40} \mathrm{~K},{ }^{238} \mathrm{Pu},{ }^{239+240} \mathrm{Pu}$ and ${ }^{90} \mathrm{Sr}$ in biological samples from King George Island (Southern Shetlands) in Antarctica. Polar Biology, 31(9), 1081-1089.

Nie, Y., Liu, X., Sun, L., Emslie, S. D. (2012). Effect of penguin and seal excrement on mercury distribution in sediments from the Ross Sea region, East Antarctica. Science of the Total Environment, 433, 132-140.

Nie, Y., Sun, L., Liu, X., Emslie, S. (2015). From warm to cold: migration of Adelie penguins within Cape Bird, Ross Island. Scientific reports, 5, 11530-11530.

Parmesan, C. (2006). Ecological and evolutionary responses to recent climate change. Annual Review of Ecology, Evolution, and Systematics, 637-669.

Pourchet, M., Magand, O., Frezzotti, M., Ekaykin, A., Winther, J. G. (2003). Radionuclides deposition over Antarctica. Journal of environmental radioactivity, 68(2), 137-158.

Preiss, N., Mélières, M. A., Pourchet, M. (1996). A compilation of data on lead 210 concentration in surface air and fluxes at the air-surface and water-sediment interfaces. Journal of Geophysical Research: Atmospheres (1984 - 2012), 101(D22), 28847-28862.

United Nations Scientific Committee on the Effects of Atomic Radiation. (1982). Ionizing radiation: sources and biological effects.

Rhodes, R., Bertler, N., Baker, J., Steen-Larsen, H. C., Sneed, S., Morgenstern, U., Johnsen, S. J. (2012). Little Ice Age climate and oceanic conditions of the Ross Sea, Antarctica from a coastal ice core record. Climate of the Past, 8(4), 1223-1238.

Roos, P., Holm, E., Persson, R., Aarkrog, A., Nielsen, S. (1994). Deposition of ${ }^{210} \mathrm{~Pb},{ }^{137} \mathrm{Cs},{ }^{239+240} \mathrm{Pu}$, ${ }^{238} \mathrm{Pu}$, and ${ }^{241} \mathrm{Am}$ in the Antarctic Peninsula area. Journal of environmental radioactivity, 24(3), 235-251.

Sanders, C. J., Santos, I. R., Patchineelam, S. R., Schaefer, C., Silva-Filho, E. V. (2010). Recent ${ }^{137}$ Cs deposition in sediments of Admiralty Bay, Antarctica. Journal of environmental radioactivity, 101(5), 421-424.

Schneider, D. P., Deser, C., Okumura, Y. (2012). An assessment and interpretation of the observed warming of West Antarctica in the austral spring. Climate Dynamics, 38(1-2), 323-347. 
Schüller, P., Bunzl, K., Voigt, G., Ellies, A., Castillo, A. (2004). Global fallout ${ }^{137}$ Cs accumulation and vertical migration in selected soils from South Patagonia. Journal of environmental radioactivity, $71(1), 43-60$.

Sinclair, K. E., Bertler, N. A., Van Ommen, T. D. (2012). Twentieth-century surface temperature trends in the western Ross Sea, Antarctica: Evidence from a high-resolution ice core. Journal of Climate, 25(10), 3629-3636.

Suzuki, T., Kamiyama, K., Furukawa, T., Fujii, Y. (2004). Lead-210 profile in firn layer over Antarctic ice sheet and its relation to the snow accumulation environment. Tellus B, 56(1), 85-92.

Taylor, R., Wilson, P. (1990). Recent increase and southern expansion of Adelie penguin populations in the Ross Sea, Antarctica, related to climatic warming. New Zealand Journal of Ecology, 25-29.

Xu, L., Liu, X., Sun, L., Yan, H., Liu, Y., Luo, Y., Huang J., Wang Y. (2010). Distribution of radionuclides in the guano sediments of Xisha Islands, South China Sea and its implication. Journal of environmental radioactivity, 101(5), 362-368. 
Fig. 1. The study area and the sampling sites in the Ross Sea region.

Fig. 2. Activities of ${ }^{210} \mathrm{~Pb},{ }^{226} \mathrm{Ra}$ and ${ }^{137} \mathrm{Cs}$ against depth and results of dating using CRS model in the profiles.

Fig. 3. ${ }^{210} \mathrm{~Pb}_{\mathrm{ex}}$ and ${ }^{137} \mathrm{Cs}$ flux in profile $\mathrm{MB} 1, \mathrm{MB} 4, \mathrm{MB} 6$ and $\mathrm{CC}$ with average deposition rate showing a decreasing trend from glacial front to near-shore penguin colonies.

Fig. 4. Deposition rate in the upper layers of profile MB1, MB4, MB6 and CC. 
Table 1 Sampling information on the ornithogenic sediments from the Ross Sea region

\begin{tabular}{|c|c|c|c|c|c|c|}
\hline \multirow{2}{*}{$\begin{array}{l}1 \\
\text { profile } \\
3\end{array}$} & \multirow{2}{*}{ depth $(\mathrm{cm})$} & \multirow{2}{*}{ location } & \multirow{2}{*}{ Coordinates } & \multicolumn{2}{|c|}{ lithology } & \multirow{2}{*}{ catchment } \\
\hline & & & & guano & algae & \\
\hline $4_{5} \mathrm{MB} 4$ & 42 & Cape Bird, Ross Island & $166^{\circ} 22^{\prime} 25.6^{\prime \prime} \mathrm{E}, 77^{\circ} 14^{\prime} 35.3^{\prime \prime} \mathrm{S}$ & moderate & major & large \\
\hline${ }_{6}^{5} \mathrm{CL} 2$ & 35 & Cape Bird, Ross Island & $166^{\circ} 22^{\prime} 25.6^{\prime \prime} \mathrm{E}, 77^{\circ} 14^{\prime} 35.3^{\prime \prime} \mathrm{S}$ & moderate & minor & large \\
\hline 7MB6 & 38 & Cape Bird, Ross Island & $166^{\circ} 26^{\prime} 44.4^{\prime \prime} \mathrm{E}, 77^{\circ} 12^{\prime} 47.5^{\prime \prime} \mathrm{S}$ & major & major & small \\
\hline${ }_{9}^{8} \mathrm{MB1}$ & 51 & Cape Bird, Ross Island & $166^{\circ} 22^{\prime} 26^{\prime \prime} \mathrm{E}, 77^{\circ} 14^{\prime} 35.7^{\prime \prime} \mathrm{S}$ & moderate & none & large \\
\hline $10 \mathrm{CC}$ & 9.5 & Cape Crozier, Ross Island & $169^{\circ} 14^{\prime} 41.3^{\prime \prime} \mathrm{E}, 77^{\circ} 27^{\prime} 21.9^{\prime \prime} \mathrm{S}$ & major & none & small \\
\hline 11 MR1 & 35 & Cape Royds, Ross Island & $166^{\circ} 09^{\prime} 55.5^{\prime \prime} \mathrm{E}, 77^{\circ} 33^{\prime} 15.2^{\prime \prime} \mathrm{S}$ & major & none & small \\
\hline${ }_{13}^{12} \mathrm{MR} 2$ & 50 & Cape Royds, Ross Island & $166^{\circ} 09^{\prime} 54.0^{\prime \prime} \mathrm{E}, 77^{\circ} 33^{\prime} 16.1^{\prime \prime} \mathrm{S}$ & major & none & small \\
\hline $14 \mathrm{BI}$ & 20.5 & Beaufort Island & $166^{\circ} 58^{\prime} 23.6^{\prime \prime} \mathrm{E}, 76^{\circ} 58^{\prime} 23.6^{\prime \prime} \mathrm{S}$ & major & major & small \\
\hline
\end{tabular}


Table 2 Activities of radionuclides in the ornithogenic sediments from the Ross Sea region

\begin{tabular}{|c|c|c|c|c|c|}
\hline Sample No. & $\begin{array}{l}\text { Depth } \\
(\mathrm{cm})\end{array}$ & $\begin{array}{l}\text { Dry Density } \\
\left(\mathrm{g} / \mathrm{cm}^{3}\right)\end{array}$ & $\begin{array}{c}{ }^{210} \mathrm{~Pb} \text { activity } \\
(\mathrm{Bq} / \mathrm{kg})\end{array}$ & $\begin{array}{c}{ }^{226} \text { Ra activity } \\
\text { (Bq/kg) }\end{array}$ & $\begin{array}{c}{ }^{137} \text { Cs activity } \\
\text { (Bq/kg) }\end{array}$ \\
\hline MB4-1 & 0.8 & 1.04 & $63.9 \pm 8.2$ & $28.7 \pm 1.6$ & $3.1 \pm 0.9$ \\
\hline MB4-2 & 1.6 & 1.15 & $74.5 \pm 13.1$ & $30.0 \pm 1.8$ & $4.1 \pm 0.8$ \\
\hline MB4-3 & 2.4 & 0.74 & $65.3 \pm 11.2$ & $30.6 \pm 1.9$ & $6.6 \pm 1.0$ \\
\hline MB4-4 & 3.2 & 0.88 & $75.6 \pm 10.3$ & $35.3 \pm 1.9$ & $5.3 \pm 0.8$ \\
\hline MB4-5 & 4 & 1.22 & $58.5 \pm 12.0$ & $38.2 \pm 1.9$ & $2.3 \pm 0.6$ \\
\hline MB4-6 & 4.8 & 1.49 & $67.0 \pm 12.5$ & $33.1 \pm 2.1$ & $1.7 \pm 0.8$ \\
\hline MB4-7 & 5.6 & 1.75 & $58.7 \pm 9.7$ & $40.1 \pm 1.9$ & $\mathrm{BDL}$ \\
\hline MB4-8 & 6.4 & 2.15 & $42.7 \pm 8.7$ & $37.3 \pm 1.7$ & BDL \\
\hline MB4-9 & 7.2 & 2.10 & $48.1 \pm 9.1$ & $44.3 \pm 2.1$ & BDL \\
\hline MB4-10 & 8 & 2.19 & $34.5 \pm 6.3$ & $36.0 \pm 1.7$ & BDL \\
\hline MB6-1 & 0.6 & 1.41 & $47.0 \pm 9.6$ & $34.8 \pm 2.5$ & $\mathrm{BDL}$ \\
\hline MB6-2 & 1.2 & 1.30 & $47.2 \pm 11.6$ & $30.3 \pm 2.1$ & $3.6 \pm 0.9$ \\
\hline MB6-3 & 1.8 & 1.66 & $45.2 \pm 10.4$ & $29.0 \pm 2.0$ & $\mathrm{BDL}$ \\
\hline MB6-4 & 2.4 & 1.46 & $56.6 \pm 11.9$ & $43.4 \pm 2.6$ & BDL \\
\hline MB6-5 & 3 & 1.40 & $40.8 \pm 7.7$ & $34.6 \pm 2.0$ & BDL \\
\hline MB6-6 & 3.6 & 1.43 & $43.9 \pm 7.3$ & $39.1 \pm 2.2$ & BDL \\
\hline MB6-7 & 4.2 & 1.38 & $25.9 \pm 8.0$ & $20.3 \pm 1.4$ & BDL \\
\hline MB6-8 & 4.8 & 1.43 & $35.1 \pm 9.2$ & $28.7 \pm 2.0$ & BDL \\
\hline MB6-9 & 5.4 & 1.66 & $33.3 \pm 6.2$ & $37.8 \pm 2.2$ & $\mathrm{BDL}$ \\
\hline CL2-1 & 0.5 & 1.10 & $76.0 \pm 12.3$ & $43.3 \pm 2.1$ & $2.8 \pm 0.8$ \\
\hline CL2-2 & 1 & 0.89 & $57.7 \pm 11.6$ & $40.9 \pm 2.1$ & $3.3 \pm 0.9$ \\
\hline CL2-3 & 1.5 & 1.41 & $67.6 \pm 12.2$ & $38.5 \pm 1.8$ & $1.1 \pm 0.4$ \\
\hline CL2-4 & 2 & 1.43 & $57.6 \pm 11.8$ & $38.3 \pm 1.8$ & $1.0 \pm 0.4$ \\
\hline CL2-5 & 2.5 & 1.56 & $63.5 \pm 11.8$ & $40.6 \pm 2.0$ & $1.3 \pm 0.6$ \\
\hline CL2-6 & 3 & 1.48 & $51.9 \pm 8.2$ & $42.1 \pm 2.0$ & $\mathrm{BDL}$ \\
\hline CL2-7 & 3.5 & 1.38 & $43.7 \pm 7.9$ & $40.7 \pm 1.8$ & $\mathrm{BDL}$ \\
\hline CL2-8 & 4 & 1.53 & $53.0 \pm 9.3$ & $46.6 \pm 2.1$ & $\mathrm{BDL}$ \\
\hline CL2-9 & 4.5 & 1.44 & $73.3 \pm 12.5$ & $47.7 \pm 2.0$ & $\mathrm{BDL}$ \\
\hline CL2-10 & 5 & 1.47 & $77.1 \pm 14.6$ & $46.8 \pm 2.2$ & $\mathrm{BDL}$ \\
\hline CL2-11 & 5.5 & 1.56 & $49.4 \pm 7.9$ & $32.8 \pm 1.6$ & $\mathrm{BDL}$ \\
\hline CL2-12 & 6 & 1.36 & $63.5 \pm 11.4$ & $33.7 \pm 1.6$ & $\mathrm{BDL}$ \\
\hline CL2-13 & 6.5 & 1.50 & $38.7 \pm 7.9$ & $30.0 \pm 1.6$ & $\mathrm{BDL}$ \\
\hline CL2-14 & 7 & 1.47 & $35.2 \pm 8.2$ & $33.9 \pm 1.7$ & $\mathrm{BDL}$ \\
\hline MB1-1 & 1 & 1.03 & $65.5 \pm 10.7$ & $11.6 \pm 0.9$ & $16.6 \pm 1.1$ \\
\hline MB1-2 & 2 & 1.40 & $41.0 \pm 7.7$ & $18.2 \pm 1.3$ & $14.6 \pm 0.9$ \\
\hline MB1-3 & 3 & 1.25 & $36.1 \pm 6.2$ & $12.7 \pm 0.9$ & $3.6 \pm 0.6$ \\
\hline MB1-4 & 4 & 1.35 & $44.8 \pm 7.9$ & $10.2 \pm 0.8$ & $1.4 \pm 0.7$ \\
\hline MB1-5 & 5 & 1.51 & $48.4 \pm 8.7$ & $19.8 \pm 1.3$ & $\mathrm{BDL}$ \\
\hline MB1-6 & 6 & 1.52 & $44.1 \pm 8.4$ & $18.3 \pm 1.3$ & BDL \\
\hline MB1-7 & 7 & 1.53 & $34.9 \pm 6.6$ & $20.6 \pm 1.4$ & BDL \\
\hline MB1-8 & 8 & 1.16 & $24.9 \pm 5.1$ & $17.8 \pm 1.1$ & $\mathrm{BDL}$ \\
\hline
\end{tabular}




\begin{tabular}{|c|c|c|c|c|c|}
\hline MB1-9 & 9 & 1.40 & $22.2 \pm 6.0$ & $19.0 \pm 1.3$ & $\mathrm{BDL}$ \\
\hline CC-1 & 0.5 & 0.70 & $36.0 \pm 7.3$ & $13.1 \pm 1.1$ & $\mathrm{BDL}$ \\
\hline CC-2 & 1 & 0.73 & $51.4 \pm 8.9$ & $25.2 \pm 1.6$ & $\mathrm{BDL}$ \\
\hline CC-4 & 2 & 0.71 & $48.8 \pm 8.6$ & $11.7 \pm 0.9$ & $\mathrm{BDL}$ \\
\hline CC-5 & 2.5 & 0.73 & $26.5 \pm 5.0$ & $6.8 \pm 0.6$ & BDL \\
\hline CC-6 & 3 & 0.73 & $32.5 \pm 6.0$ & $9.5 \pm 0.8$ & $\mathrm{BDL}$ \\
\hline CC-7 & 3.5 & 0.77 & $22.9 \pm 4.7$ & $2.8 \pm 0.3$ & $\mathrm{BDL}$ \\
\hline CC-8 & 4 & 0.75 & $12.7 \pm 2.7$ & $2.5 \pm 0.3$ & $\mathrm{BDL}$ \\
\hline CC-9 & 4.5 & 0.76 & $14.4 \pm 3.0$ & $7.4 \pm 0.7$ & $\mathrm{BDL}$ \\
\hline CC-10 & 5 & 0.75 & $15.6 \pm 3.1$ & $10.0 \pm 0.7$ & $\mathrm{BDL}$ \\
\hline MR1-1 & 1 & I & $95.8 \pm 12.5$ & $22.7 \pm 1.5$ & $2.0 \pm 0.7$ \\
\hline MR1-2 & 2 & / & $98.2 \pm 8.3$ & $22.4 \pm 1.3$ & $1.4 \pm 0.8$ \\
\hline MR1-3 & 3 & / & $129.7 \pm 17.0$ & $30.3 \pm 2.1$ & $1.7 \pm 0.7$ \\
\hline MR1-4 & 4 & / & $79.9 \pm 11.7$ & $21.8 \pm 1.4$ & $1.9 \pm 0.5$ \\
\hline MR1-5 & 5 & / & $55.9 \pm 10.2$ & $18.7 \pm 1.4$ & $2.0 \pm 0.8$ \\
\hline MR1-6 & 6 & / & $35.4 \pm 6.4$ & $22.9 \pm 1.5$ & $1.7 \pm 0.8$ \\
\hline MR1-7 & 7 & / & $46.7 \pm 8.3$ & $22.4 \pm 1.7$ & $\mathrm{BDL}$ \\
\hline MR1-8 & 8 & / & $61.4 \pm 10.1$ & $24.3 \pm 1.6$ & $\mathrm{BDL}$ \\
\hline MR1-9 & 9 & / & $40.5 \pm 7.5$ & $17.3 \pm 1.0$ & $\mathrm{BDL}$ \\
\hline MR1-10 & 10 & I & $28.2 \pm 5.7$ & $24.0 \pm 1.8$ & $\mathrm{BDL}$ \\
\hline MR2-1 & 1 & I & $76.5 \pm 10.4$ & $14.3 \pm 1.0$ & $\mathrm{BDL}$ \\
\hline MR2-2 & 2 & I & $90.6 \pm 15.1$ & $20.0 \pm 1.6$ & BDL \\
\hline MR2-3 & 3 & I & $72.3 \pm 14.3$ & $20.9 \pm 1.8$ & BDL \\
\hline MR2-4 & 4 & I & $74.9 \pm 13.8$ & $20.1 \pm 1.6$ & $\mathrm{BDL}$ \\
\hline MR2-5 & 5 & / & $76.9 \pm 14.5$ & $22.6 \pm 2.0$ & $\mathrm{BDL}$ \\
\hline MR2-6 & 6 & / & $26.6 \pm 5.8$ & $21.4 \pm 1.7$ & $\mathrm{BDL}$ \\
\hline MR2-7 & 7 & I & $89.8 \pm 16.4$ & $27.0 \pm 2.4$ & $\mathrm{BDL}$ \\
\hline MR2-8 & 8 & / & $47.8 \pm 12.1$ & $20.6 \pm 1.7$ & $\mathrm{BDL}$ \\
\hline MR2-9 & 9 & / & $45.6 \pm 9.9$ & $30.8 \pm 2.3$ & $\mathrm{BDL}$ \\
\hline MR2-10 & 10 & 1 & $31.2 \pm 6.2$ & $16.3 \pm 1.5$ & $\mathrm{BDL}$ \\
\hline $\mathrm{BI}-1$ & 0.5 & 0.58 & $89.6 \pm 15.0$ & $28.0 \pm 1.7$ & $2.9 \pm 1.2$ \\
\hline $\mathrm{BI}-2$ & 1 & 0.55 & $62.3 \pm 10.0$ & $28.0 \pm 1.7$ & $2.2 \pm 0.7$ \\
\hline $\mathrm{BI}-3$ & 1.5 & 0.64 & $49.3 \pm 9.6$ & $30.4 \pm 1.7$ & $1.6 \pm 0.8$ \\
\hline $\mathrm{BI}-4$ & 2 & 0.81 & $40.8 \pm 8.2$ & $29.4 \pm 1.7$ & $3.5 \pm 0.7$ \\
\hline $\mathrm{BI}-5$ & 2.5 & 0.66 & $34.8 \pm 7.1$ & $25.8 \pm 1.7$ & $\mathrm{BDL}$ \\
\hline BI-6 & 3 & 0.61 & $36.7 \pm 7.2$ & $29.6 \pm 1.7$ & $\mathrm{BDL}$ \\
\hline $\mathrm{BI}-7$ & 3.5 & 0.74 & $42.8 \pm 7.7$ & $40.4 \pm 2.1$ & $\mathrm{BDL}$ \\
\hline $\mathrm{BI}-8$ & 4 & 1.05 & $32.9 \pm 5.8$ & $31.9 \pm 1.7$ & BDL \\
\hline
\end{tabular}

"/": not determined

BLD: below detection limit 
Table 3 Correlations between ${ }^{210} \mathrm{~Pb}_{\text {ex }}$ and TOC, $\mathrm{P}$ in the profiles

*: significant at the 0.05 level

\begin{tabular}{ccc}
\hline profile & $r^{2}$ for TOC- ${ }^{210} \mathrm{~Pb}_{\mathrm{ex}}$ & $\mathrm{r}^{2}$ for $\mathrm{P}_{-}^{210} \mathrm{~Pb} \mathrm{ex}$ \\
\hline MB4 & $0.66^{*}(\mathrm{n}=10)$ & $0.20^{* *}(\mathrm{n}=7)$ \\
MB6 & $0.10^{* *}(\mathrm{n}=9)$ & $0.046^{* *}(\mathrm{n}=3)$ \\
$\mathrm{CL2}$ & $0.10^{* *}(\mathrm{n}=14)$ & $0.01^{* *}(\mathrm{n}=8)$ \\
$\mathrm{BI}$ & $0.57^{*}(\mathrm{n}=8)$ & $0.93^{*}(\mathrm{n}=6)$ \\
CC & $0.21^{* *}(\mathrm{n}=9)$ & $0.56^{* *}(\mathrm{n}=4)$ \\
MB1 & $0.16^{* *}(\mathrm{n}=9)$ & $0.0012^{* *}(\mathrm{n}=9)$ \\
MR1 & $0.17^{* *}(\mathrm{n}=10)$ & $0.53^{* * *}(\mathrm{n}=10)$ \\
MR2 & $0.028^{* *}(\mathrm{n}=10)$ & $0.19^{* *}(\mathrm{n}=10)$ \\
\hline
\end{tabular}

$* *$ : not significant at the 0.05 level

$* * *$ : negative correlation significant at the 0.05 level 
Table 4 Calculated deposition rates and ${ }^{210} \mathrm{~Pb}_{\mathrm{ex}}$ inventories and fluxes

\begin{tabular}{|c|c|c|c|c|c|c|}
\hline $\begin{array}{l}1 \\
2 \\
3\end{array}$ & profile & $\begin{array}{l}\text { average deposition } \\
\text { rate }\left(\mathrm{g} / \mathrm{cm}^{2} \mathrm{a}\right)\end{array}$ & $\begin{array}{c}{ }^{210} \mathrm{~Pb}_{\mathrm{ex}} \text { inventory } \\
\left(\mathrm{Bq} / \mathrm{m}^{2}\right)\end{array}$ & $\begin{array}{c}{ }^{210} \mathrm{~Pb}_{\mathrm{ex}} \text { flux } \\
\left(\mathrm{Bq} / \mathrm{m}^{2} \mathrm{a}\right)\end{array}$ & $\begin{array}{c}{ }^{137} \mathrm{Cs} \text { inventory } \\
\left(\mathrm{Bq} / \mathrm{m}^{2}\right)\end{array}$ & $\begin{array}{l}{ }^{137} \mathrm{Cs} \text { flux } \\
\left(\mathrm{Bq} / \mathrm{m}^{2} \mathrm{a}\right)\end{array}$ \\
\hline 4 & MB1 & 0.1214 & 2801.56 & 87.24 & 439.14 & 10.09 \\
\hline $\begin{array}{l}5 \\
6\end{array}$ & MB4 & 0.0783 & 2181.11 & 67.92 & 182.56 & 4.19 \\
\hline 7 & MB6 & 0.0706 & 663.79 & 20.67 & 27.93 & 0.64 \\
\hline 8 & $\mathrm{CC}$ & 0.0406 & 757.21 & 23.58 & BDL & BDL \\
\hline
\end{tabular}

BLD: below detection limit 
Table 5 Flux of ${ }^{210} \mathrm{~Pb}_{\mathrm{ex}}$ determined on different sources across Antarctica

\begin{tabular}{|c|c|c|c|}
\hline region & source & reference & ${ }^{210} \mathrm{~Pb}_{\mathrm{ex}}$ flux $\left(\mathrm{Bq} / \mathrm{m}^{2} \mathrm{a}\right)$ \\
\hline the Ross Sea region & ornithogenic sediment & this study & $20.67 \sim 87.24$ \\
\hline McMurdo Dry Valley & lacustrine sediment & Doran et al., 1999 & $0.15^{\sim 16.61}$ \\
\hline $\begin{array}{c}\text { Signy Island, Antarctica } \\
\text { Peninsula }\end{array}$ & lacustrine sediment & Appleby et al., 1995 & $32 \sim 137$ \\
\hline $\begin{array}{c}\text { South Shetland, Antarctica } \\
\text { Peninsula }\end{array}$ & lacustrine sediment & Roos et al., 1994 & $1.25 \sim 8.72$ \\
\hline $60 \sim 90^{\circ} \mathrm{S}$ & atmospheric precipitation & Preiss et al., 1996 & 3.5 \\
\hline Antarctica & atmospheric precipitation & Appleby, 2008 & 5.5 \\
\hline
\end{tabular}



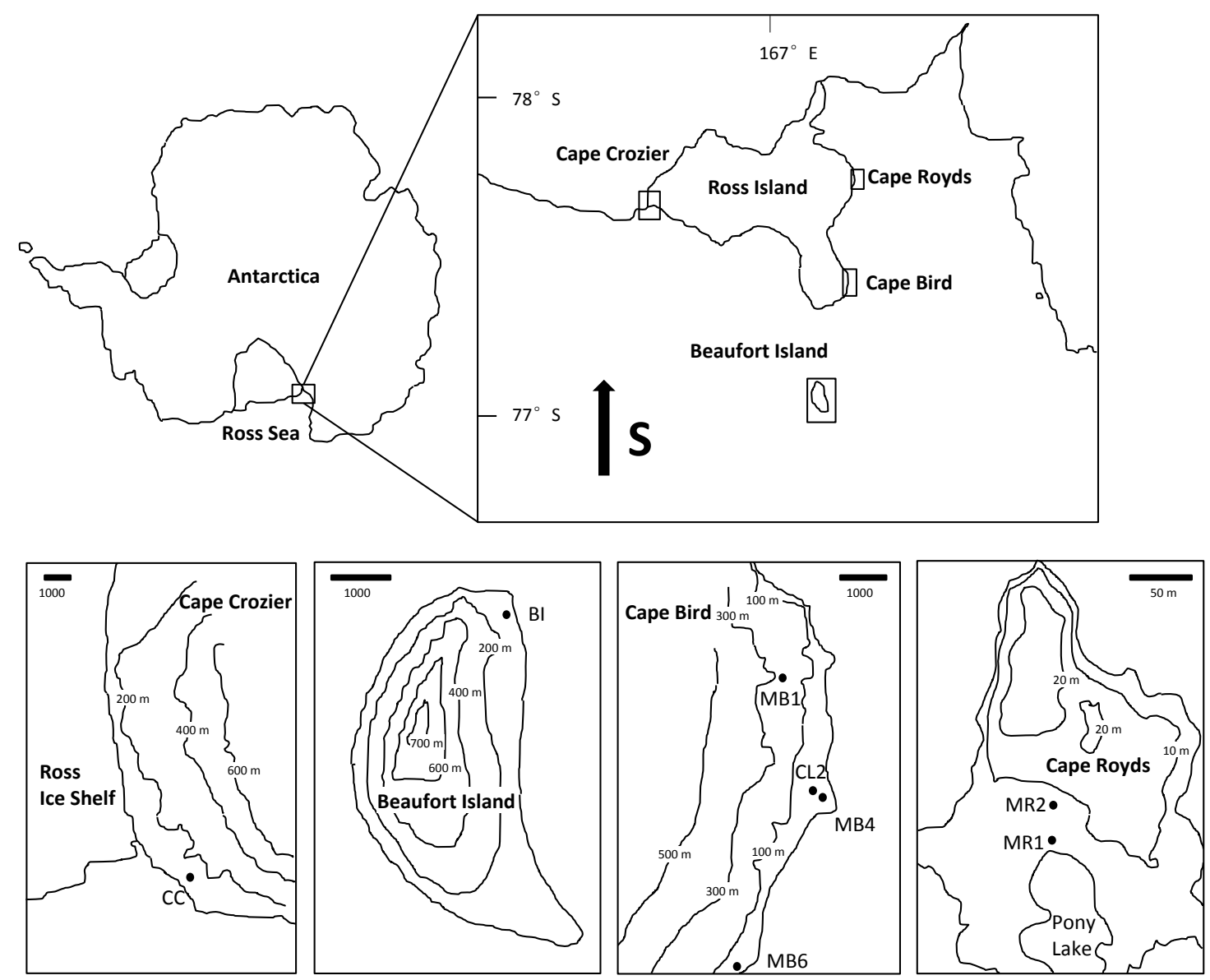

Figure 1 
Figure 2

1
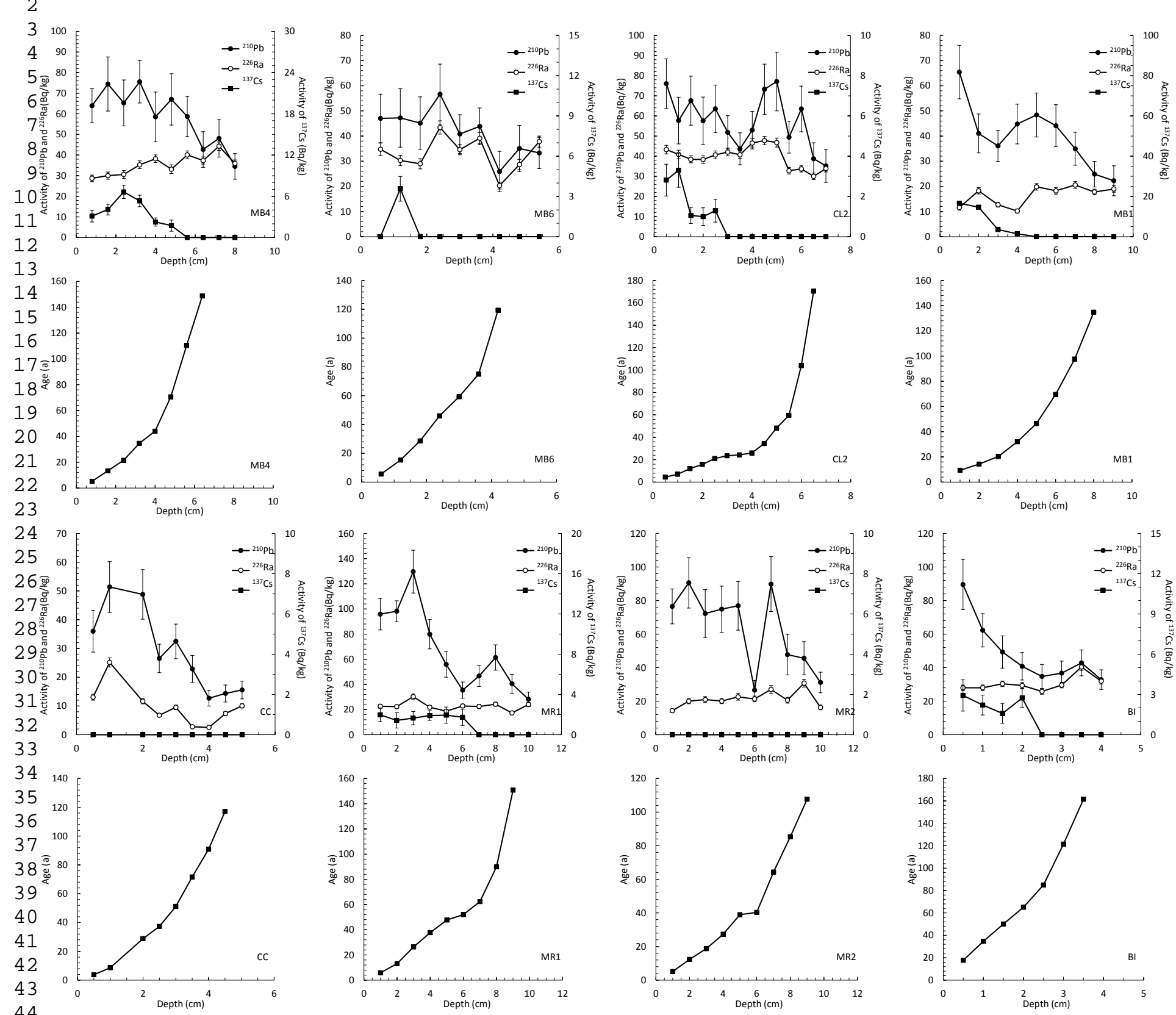

Figure 2 


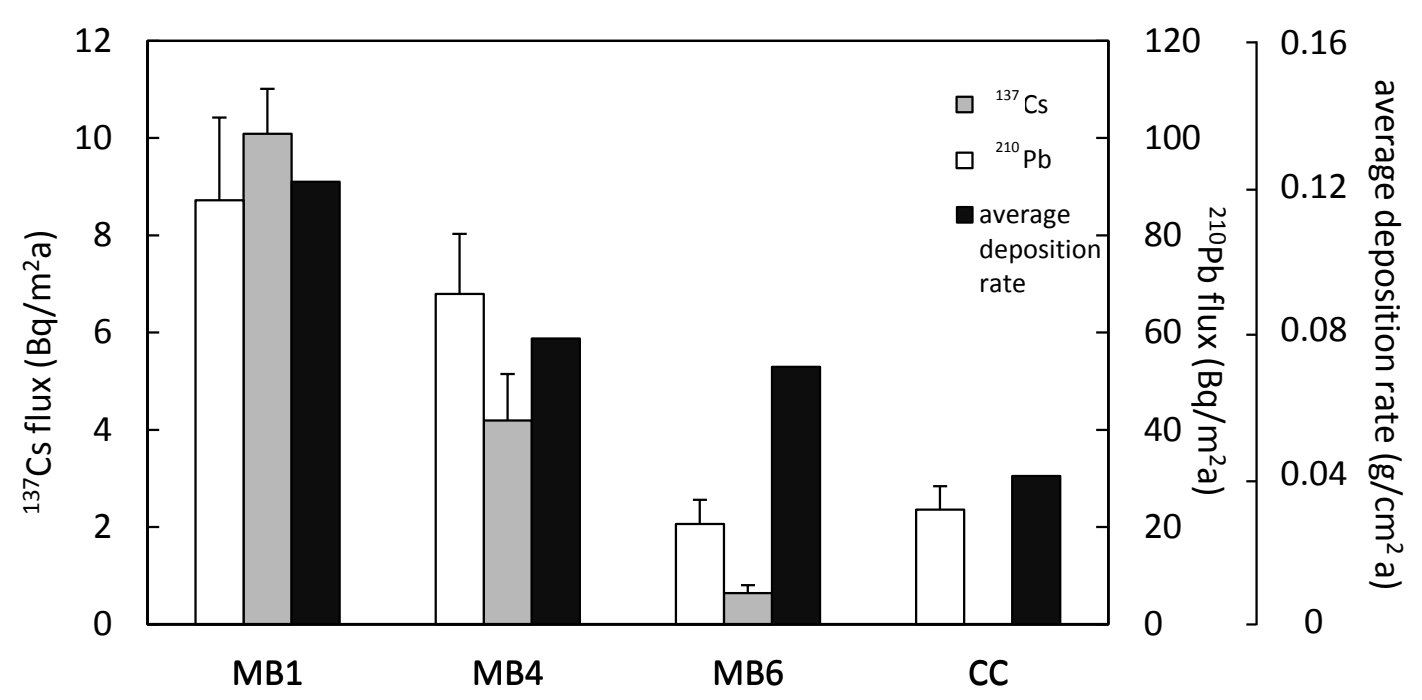

Figure 3 

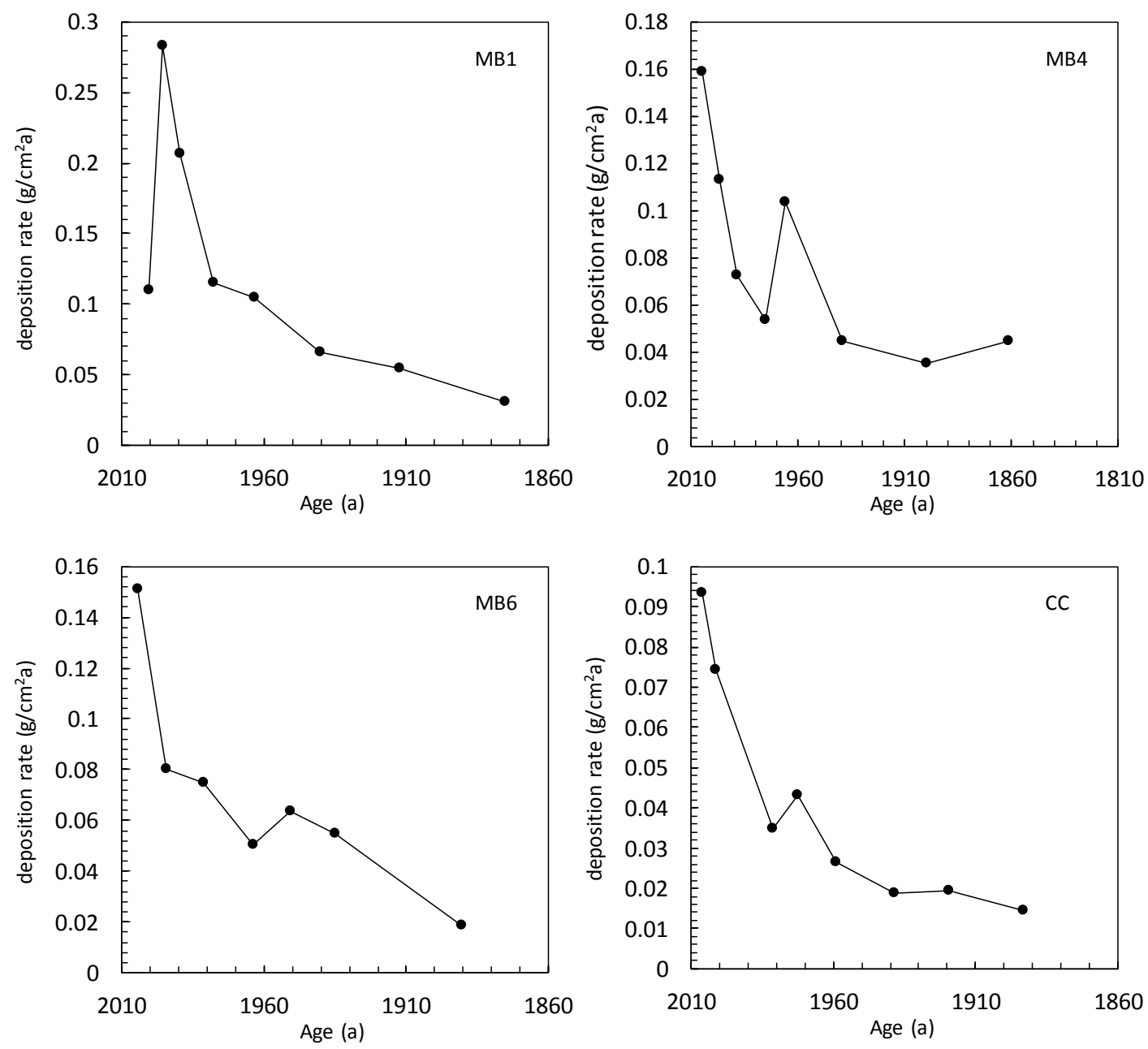

Figure 4 